\title{
Fermentabilitas Ransum yang Mengandung Ampas Bir dalam Cairan Rumen (In Vitro)
}

\author{
Ration Fermentability Containing Beer Pulp in Rumen Liquid (In Vitro)
}

\author{
F. A. Wandra, A. K. Pranowo, I. Hernaman, U. H. Tanuwiria, dan B. Ayuningsih \\ Fakultas Peternakan Universitas Padjadjaran \\ Jalan Raya Bandung - Sumedang Km. 21, Jatinangor, Sumedang, 45363 \\ Corresponding email: iman.hernaman@unpad.ac.id
}

\begin{abstract}
In vitro evaluation was carried out to determine the fermentability of rations containing beer pulp in rumen fluid (in vitro). The study used a randomized block design with 5 treatments and 4 groups. The treatment consists of rations containing $0,7,14,21$, and $28 \%$ beer pulp. The collected data was analyzed by the Duncan test. The results showed that beer pulp-containing rations up to $28 \%$ did not affect the population of bacteria and rumen protozoa, but had an effect on reducing $(\mathrm{P}<0.05)$ the concentration of $\mathrm{N}_{-} \mathrm{NH}_{3}$ and VFA along with the high amount of beer pulp. The population of bacteria and protozoa is $1.45-2.0410^{11} \mathrm{sel} / \mathrm{mL}$ and $7.75-12.6010^{7}$ cells/mL, respectively. Significant decrease in $\mathrm{N}-\mathrm{NH}_{3}$ concentration $(\mathrm{P}<0.05)$ was begun in the treatment of the use of $21 \%$ beer pulp, while in VFA it occurred in the treatment of using $7 \%$ beer pulp. Conclusion, The use of high beer pulp can affect ration fermentability and produce low fermentation products.
\end{abstract}

Key words: beer pulp, fermentability, in vitro, rumen

\begin{abstract}
ABSTRAK
Evaluasi in vitro dilakukan untuk mengetahui fermentabilitas ransum yang mengandung ampas bir dalam cairan rumen (in vitro). Penelitan menggunakan rancangan acak kelompok dengan 5 perlakuan dan 4 kelompok. Perlakuan terdiri atas ransum yang mengandung $0,7,14,21$, dan 28\% ampas bir. Data yang terkumpul dianalisis dengan uji Duncan. Hasil menunjukan bahwa ransum yang mengandung ampas bir sampai 28\% tidak mempengaruhi populasi bakteri dan protozoa rumen, namun berdampak menurunkan $(\mathrm{P}<0,05)$ konsentrasi $\mathrm{N}$ $\mathrm{NH}_{3}$ dan VFA seiring dengan jumlah ampas bir yang tinggi. Populasi bakteri dan protozoa masing-masing berjumlah $1,45-2,0410^{11} \mathrm{sel} / \mathrm{mL}$ dan $7,75-12,6010^{7} \mathrm{sel} / \mathrm{mL}$. Penurunan konsentrasi $\mathrm{N}-\mathrm{NH}_{3}$ yang nyata $(\mathrm{P}<0,05)$ dimulai pada perlakuan penggunaan $21 \%$ ampas bir, sedangkan pada VFA terjadi pada perlakuan penggunaan $7 \%$ ampas bir. Kesimpulan, Penggunaan ampas bir yang tinggi dapat mempengaruhi fermentabilitas ransum dan menghasilkan produk fermentasi yang rendah.
\end{abstract}

Kata kunci : ampas bir, fermentabilitas, in vitro, rumen

\section{PENDAHULUAN}

Ampas bir adalah sisa fermentasi yang sebagian besar terdiri atas pati dan gula dari gandum pada saat pembuatan bir (Cullison, 1978). Ampas bir mengandung $27,5 \%$ protein kasar; 6,5\% lemak kasar; 14,21\% serat kasar; $41,1 \%$ BETN; 0,29\% kalsium; dan 0,48\% phospor (Morrison, 1961). Kandungan protein yang tinggi mengindikasikan ampas bir dapat digunakan sebagai bahan pakan sumber protein.

Pemanfaatan ampas bir telah umum digunakan sebagai pakan ternak ruminansia terutama pada sapi dan domba (Briggs, 1978). Pemberian ampas bir untuk sapi dalam bentuk bahan kering adalah $10-30 \%$ dari ransum, sedangkan dalam bentuk basah adalah sebesar 9 $14 \mathrm{~kg}$ (Morrison, 1961). Penggunaan ampas bir yang efektif dalam bentuk kering sebanyak 30 40\% dari bahan kering konsentrat (King, 1974).

Tingginya nilai protein kasar dan karbohidrat terlarut yang terkandung dalam ampas bir akan mempengaruhi populasi mikroba rumen. Di dalam rumen terdapat banyak variasi dan jumlah dari populasi mikroba. Mikroorganisme dalam rumen dapat dibagi dalam tiga kelompok utama, yaitu bakteri, protozoa, dan fungi (Czerkawski, 1986; Purbowati et al. 2014). Bakteri, protozoa, dan fungi ini hidup dalam hubungan simbiosis atau mutualistis (Kreier \& Baker, 1993) dan melakukan aktivitas fermentasi di dalam rumen. Hasil akhir produk dari fermentasi yang dilakukan oleh protozoa seringkali sama dengan yang dihasilkan oleh bakteri rumen (Czerkawski, 1986). 
Seluruh protein yang berasal dari makanan pertama kali dihidrolisa oleh mikroba rumen (Arora, 1989). Baik bakteri maupun protozoa dapat mencerna protein. Hidrolisa protein menjadi asam amino diikuti oleh proses deaminasi untuk membebaskan ammonia $(\mathrm{N}$ $\mathrm{NH}_{3}$ ). Amonia yang dibebaskan dalam rumen sebagian dimanfaatkan oleh mikroba untuk mensintesis protein mikroba. Sementara itu, karbohidrat pakan difermentasi oleh mikroba rumen menjadi volatile fatty acid (VFA). Produk fermentasi ini digunakan sebagai sumber energi baik untuk mikroba rumen maupun induk semang.

\section{MATERI DAN METODE}

\section{Ransum Percobaan}

Ampas bir yang digunakan dalam penelitian ini berasal dari limbah pembuatan bir pada PT. Delta Djakarta Tbk. Bahan pakan tersebut merupakan bagian ransum percobaan dan digunakan dalam konsentrat sebanyak 0, 7, 14, 21 dan 28\%. Ransum basal terdiri atas $30 \%$ rumput dan $70 \%$ konsentrat. Komposisi bahan dan kandungan zat makanan ransum konsentrat percoban disajikan dalam Tabel 1.

\section{Pelaksanaan In Vitro}

Prosedur pelaksanaan in vitro mengacu pada metode Tilley dan Terry
(1963). Sampel bahan ditimbang dan dimasukkan sebanyak $0,5 \mathrm{~g}$ untuk setiap tabung. Saliva buatan sebanyak $40 \mathrm{ml}$ dan cairan rumen domba sebanyak $10 \mathrm{~mL}$ dimasukkan ke dalam tabung fermentor yang telah berisi sampel. Gas $\mathrm{CO}_{2}$ dialirkan ke dalam tabung, kemudian tabung fermentor tersebut ditutup dengan menggunakan tutup karet berpentil. Tabung fermentor dimasukkan ke dalam rak yang telah tersedia di dalam waterbath dengan pengaturan suhu $39^{\circ}-40^{\circ} \mathrm{C}$. Lama inkubasi adalah 3 dan 24 jam sambil melakukan pengocokkan secara kontinyu setiap 30 menit.

Sampel dengan lama inkubasi 3 jam dilakukan proses sentrifugasi selama 10 menit untuk mendapatkan supernatant yang digunakan dalam analisis VFA dan analisis $\mathrm{N}^{-\mathrm{NH}_{3}}$. Sementara sampel dengan lama inkubasi 24 jam disaring dengan menggunakan kain muslin diambil untuk dilakukan analisis total bakteri dan protozoa.

\section{Pengukuran Total Bakteri}

Cairan rumen sebanyak $0,5 \mathrm{~mL}$ dicampur dengan $4,5 \mathrm{~mL}$ larutan formalsaline $10 \%$ yang terdiri atas $1,35 \mathrm{ml}$ formaldehyde $35 \%$ dalam $3,65 \mathrm{ml} \mathrm{NaCl}$ 0,9\%. Kemudian dilakukan pengenceran hingga $10^{-4}$. Formaldehide yang ada pada larutan ini akan menyebabkan bakteri mati tetapi proses lisis dapat dicegah dengan adanya

Tabel 1. K omposisi bahan pakan dan kandungan zat makanan ransum percobaan

\begin{tabular}{lccccc}
\hline Bahan Pakan & R0 & R1 & R2 & R3 & R4 \\
\hline Rumput lapang (\%) & 30 & 30 & 30 & 30 & 30 \\
Konsentrat (\%) & 70 & 70 & 70 & 70 & 70 \\
$\quad$ Ampas bir (\%) & 0,00 & 7,00 & 14,00 & 21,00 & 28,00 \\
$\quad$ Dedak padi (\%) & 10,66 & 8,75 & 5,60 & 2,80 & 0,70 \\
$\quad$ Pollard (\%) & 26,78 & 19,60 & 14,00 & 5,60 & 0,70 \\
$\quad$ Onggok (\%) & 14,97 & 21,12 & 27,21 & 33,96 & 39,55 \\
$\quad$ Bungkil kopra (\%) & 17,25 & 13,18 & 8,84 & 6,29 & 0,70 \\
$\quad$ Mineral mix (\%) & 0,35 & 0,35 & 0,35 & 0,35 & 0,35 \\
\hline Kandungan Zat Makanan & & & & & \\
\hline Bahan kering (\%) & 83,60 & 83,61 & 83,55 & 83,60 & 83,51 \\
Abu (\%) & 7,00 & 6,36 & 5,60 & 4,89 & 4,21 \\
Protein kasar (\%) & 13,59 & 13,66 & 13,80 & 13,87 & 13,99 \\
Lemak kasar (\%) & 5,77 & 5,45 & 5,06 & 4,79 & 4,38 \\
Serat kasar (\%) & 16,27 & 16,80 & 17,10 & 17,72 & 18,00 \\
Bahan ekstrak tanpa nitrogen (BETN) & 57,03 & 57,39 & 58,09 & 58,38 & 59,08 \\
Total digestible nutrient (TDN) & 60,87 & 60,54 & 60,38 & 60,12 & 59,85 \\
\hline
\end{tabular}


tekanan isotonis dari $\mathrm{NaCl}$ fisiologis. Sel bakteri yang dihitung pada metode ini dalam keadaan mati dan untuk memudahkan penghitungannya, digunakan sampel yang telah diencerkan sampai $10^{-4}$. Selanjutnya meneteskan sampel sebanyak 1 tetes pada bagian tengah counting chamber yang telah ditutup dengan cover glass dan kemudian mengamati serta menghitung jumlah bakteri di bawah mikroskop dengan pembesaran 1000 kali. Terakhir dilakuan penghitungan jumlah total bakteri menggunakan kotak kecil yang terdapat pada counting chamber dengan ukuran $0,1 \times 0,05$ x $0,05 \mathrm{~mm}$ sebanyak 40 buah dimana 1 kotak volumenya adalah $1 / 4000 \mathrm{~m}^{3}$, sehingga dapat diketahui volumenya yaitu $40 \times 1 / 10 \times 1 / 20 \times$ $1 / 20=1 / 100 \mathrm{~mm}^{3}$ atau setara dengan $10^{-5} \mathrm{~mL}$. Jika dalam 40 kotak ditemukan b bakteri, artinya dalam $10^{-5} \mathrm{~mL}$ cairan rumen terdapat $\mathrm{b} \times 10^{4}$ bakteri. Maka dalam $1 \mathrm{~mL}$ cairan rumen terdapat: Total Bakteri $=\mathrm{b} \times 1 / \mathrm{FP} \times 1 /$ volume

$$
\begin{aligned}
& =\mathrm{b} \times 10^{4} \times 10^{9} \\
& =\mathrm{b} \times 10^{9} \text { sel bakteri }
\end{aligned}
$$

Keterangan: $\quad \mathrm{FP}=$ Faktor pengenceran

\section{Pengukuran Total Protozoa}

Mencampur cairan rumen yang telah disaring dengan 4,5 mL larutan Methylgreen Formaldehide Saline (MFS) yang terdiri atas 0,7 g methylgreen, $100 \mathrm{~mL}$ formaldehyde $35 \%, 8 \mathrm{~g}$ $\mathrm{NaCl}$, dan $900 \mathrm{ml}$ aquadest. Methylgreen yang ada pada larutan ini akan mewarnai nukleus sel protozoa sehingga memudahkan penghitungannya. Formaldehide berfungsi untuk membunuh sel protozoa dan proses lisis akan dicegah dengan penambahan $\mathrm{NaCl}$ fisiologis. Cairan ini didiamkan sekurang-kurangnya selama 30 menit agar pewarnaan nukleus sempurna. Selanjutnya dilakukan pemeriksaan di bawah mikroskop dengan pembesaran 400 kali dan menghitung total protozoa dengan menggunakan 25 kotak besar dengan ukuran per kotak $0,1 \times 0,2$ x $0,2 \mathrm{~mm}^{3}$, sehingga volume dari 25 kotak besar adalah $25 \times 1 / 10 \times 1 / 5 \times 1 / 5=1 / 10 \mathrm{~mm}^{3}$ atau setara dengan $10^{-4} \mathrm{~mL}$. Jadi, dalam $1 \mathrm{~mL}$ cairan rumen terdapat:

Total Protozoa : p x 1/FP x 1/Volume

$$
\begin{aligned}
& =\mathrm{p} \times 10^{1} \times 10^{4} \\
& =\mathrm{p} \times 10^{5} \mathrm{sel} \text { protozoa }
\end{aligned}
$$

\section{Prosedur Pengukuran $\mathrm{N}_{-} \mathrm{NH}_{3}$ Cairan Rumen}

Kadar $\mathrm{N}^{-\mathrm{NH}_{3}}$ ditentukan dengan menggunakan metode mikrodifusi pada cawan Conway yang dijelaskan oleh Hernaman et al.
(2015). Sebanyak $1 \mathrm{~mL}$ supernatan diletakkan di sebelah kiri sket cawan Conway dan $1 \mathrm{~mL} \mathrm{NaOH}$ ditempatkan dekat sebelah kanan. Pada cawan kecil di bagian tengah diisi dengan asam borat berindikator merah metil dan brom kresol hijau sebanyak $1 \mathrm{ml}$. Kemudian cawan Conway ditutup rapat dengan tutup bervaselin lalu digoyanggoyang sehingga supernatan bercampur dengan larutan $\mathrm{NaOH}$. Cawan dibiarkan selama 24 jam pada suhu kamar. Amonia $\left(\mathrm{N}^{-\mathrm{NH}_{3}}\right)$ yang terikat dengan asam borat dititrasi dengan $\mathrm{H}_{2} \mathrm{SO}_{4}$ $0,005 \mathrm{~N}$ sampai warna berubah menjadi kemerahmerahan. Kadar $\mathrm{N}^{-\mathrm{NH}_{3}}$ dihitung dengan rumus sebagai berikut:

$\mathrm{N}-\mathrm{NH}_{3}=\left(\mathrm{mL}\right.$ titrasi $\left.\times \mathrm{N} \mathrm{H}_{2} \mathrm{SO}_{4} \times 1000\right) \mathrm{mM}$

\section{Prosedur Pengukuran VFA Cairan Rumen}

Pengukuran kadar total asam lemak volatil dilakukan dengan menggunakan seperangkat alat destilasi uap Markham yang dijelaskan oleh Hernaman et al. (2015). Sebanyak $5 \mathrm{~mL}$ supernatan dimasukkan ke dalam tabung destilasi uap yang dipanaskan dengan uap air. Tabung segera ditutup rapat setelah ditambahkan $1 \mathrm{~mL} \mathrm{H}_{2} \mathrm{SO}_{4} 15 \%$. Uap air panas akan membawa asam lemak volatil melewati tabung pendingin sehingga akan terkondensasi dan ditampung dengan Erlenmeyer berisi $5 \mathrm{~mL}$ $\mathrm{NaOH} 0,5 \mathrm{~N}$ sampai mencapai volume sekitar $300 \mathrm{~mL}$. Selanjutnya ditambahkan indikator phenolptalein 2 tetes dan dititrasi dengan $\mathrm{HCl}$ 0,5 N. Titrasi berakhir pada saat titik awal perubahan warna dari merah menjadi bening. Terakhir, $5 \mathrm{ml} \mathrm{NaOH} 0,5 \mathrm{~N}$ dititrasi dan digunakan sebagai blanko. Kadar total asam lemak volatil dihitung dengan rumus:

Total asam lemak volatil $=(\mathrm{b}-\mathrm{s}) \times \mathrm{N} \mathrm{HCl} \mathrm{x}$ $1000 / 5 \mathrm{mM}$

Keterangan: $\mathrm{b}=$ vol. titran blanko, $\mathrm{N}=$ normalitas larutan $\mathrm{HCl}, \mathrm{s}=$ vol. titran sampel.

\section{Analisis Statistik}

Penelitian ini dilakukan dengan metode eksperimental. Rancangan yang digunakan adalah Rancangan Acak Kelompok (RAK) dengan lima perlakuan dan empat kelompok cairan rumen dari domba yang berbeda, dimana kelompok sebagai ulangan, sehingga terdapat 20 unit percobaan (Gaspersz, 1995). 


\section{HASIL DAN PEMBAHASAN}

\section{Pengaruh Perlakuan terhadap Jumlah Bakteri Rumen}

Bakteri merupakan biomassa mikroba rumen yang jumlah dan jenisnya paling banyak. Mikroba ini memiliki peranan utama dalam mencerna pakan. Jumlah bakteri cairan rumen (in vitro) dari berbagai perlakuan disajikan pada Tabel 2. Data Tabel 2 memperlihatkan adanya perubahan jumlah bakteri dengan penambahan ampas bir dalam ransum, tetapi perubahannya tidak terlalu besar. Nilai rataan total bakteri di atas tampak cukup tinggi, yaitu mencapai nilai $10 \mathrm{se} / \mathrm{mL}$, namun nilai tersebut masih dalam kondisi yang normal. Menurut Stewart dalam Jouany (1991), jumlah bakteri rumen tersebut dimungkinkan mencapai $10^{10}$ sampai $10{ }^{11} \mathrm{sel} / \mathrm{mL}$. Pada tabel yang sama tampak nilai rataan total bakteri tertinggi diperoleh pada penggunaan ransum kontrol (R0), yaitu sebanyak 2,04 x 11

$10 \mathrm{sel} / \mathrm{mL}$, kemudian diikuti oleh penggunaan

$28 \%$ ampas bir (R4) sebanyak 1,93 x 10 $\mathrm{sel} / \mathrm{mL}, 7 \%$ ampas bir (R1) sebanyak 1,72 x 11

$10 \mathrm{sel} / \mathrm{mL}, 14 \%$ ampas bir (R2) sebanyak 1,46 x $10^{11} \mathrm{sel} / \mathrm{mL}$, dan nilai terendah diperoleh pada penggunaan $21 \%$ ampas bir (R3), yaitu sebanyak $1,45 \times 10 \mathrm{sel} / \mathrm{mL}$.

Hasil analisis Duncan menunjukkan bahwa penggunaan ampas bir tidak menyebabkan adanya perbedaan yang nyata terhadap perubahan jumlah bakteri dalam cairan rumen domba. Hal ini berarti, penggunaan ampas bir pada berbagai tingkat tidak mengganggu jumlah bakteri dalam cairan rumen. Kemungkinan hal ini terjadi karena kualitas ransum setiap perlakuan pada penelitian ini relatif sama. Dapat dilihat bahwa kandungan zat makanan pada setiap ransum penelitian tidak berbeda jauh (Tabel 1).

Ditinjau dari kandungan zat makanan masing-masing ransum penelitian, setiap perlakuan mempunyai kandungan energi dan protein yang relatif sama (isoenergi dan isoprotein). Selain itu, kandungan serat kasar masing-masing ransum penelitian juga tidak berbeda jauh yaitu berkisar antara 16,27 17,99\%. Berdasarkan hal-hal tersebut, maka jumlah bakteri yang dihasilkan pada setiap perlakuan tidak jauh berbeda. Seperti yang dikemukakan oleh Yokohama dan Johnson (1988), bahwa populasi mikroba dan proporsi dari spesiesnya tersebut tidaklah tetap, namun dalam kondisi yang berubah-ubah. Perubahan ini akan mencapai keseimbangan baru yang sesuai dengan perubahan pakan, sebab jenis dan kandungan nutrien pakan yang dikonsumsi oleh ternak dapat mempengaruhi kondisi lingkungan rumen.

Ampas bir mempunyai kandungan protein yang tinggi. Tingginya kandungan protein dalam ampas bir tersebut diduga mampu merangsang pertumbuhan bakteri proteolitik dan amilolitik, sehingga dapat meningkatkan populasi mikroba rumen. Protein yang masuk ke dalam rumen akan mengalami perombakan oleh enzim proteolitik yang diproduksi oleh mikroba rumen. Perombakan protein yang dilakukan oleh enzim proteolitik di dalam rumen akan menghasilkan molekul peptida dan asam amino. Substansi ini sebagian besar akan mengalami deaminasi lebih lanjut, sehingga dihasilkan ammonia $\left(\mathrm{N}-\mathrm{NH}_{3}\right)$.

Amonia dibutuhkan oleh bakteri sebagai sumber nitrogen yang digunakan dalam membangun selnya. Mikroorganisme tidak dapat berkembangbiak dalam rumen jika suplai nitrogen atau mineral dalam rumen terbatas (Arora, 1989).

Tabel 2. Rataan bakteri rumen pada berbagai perlakuan ransum yang mengandung ampas bir

\begin{tabular}{cccccc}
\hline \multirow{3}{*}{ Kelompok } & \multicolumn{5}{c}{ Perlakuan } \\
\cline { 2 - 6 } & R0 & R1 & R2 & R3 & R4 \\
\cline { 2 - 6 } & & $\ldots \ldots \ldots \ldots \ldots \ldots \times$ & $10^{11}$ & sel/ml cairan rumen..................... \\
\hline 1 & 1,40 & 1,95 & 1,05 & 1,28 & 0,99 \\
2 & 2,50 & 1,98 & 1,86 & 1,18 & 2,62 \\
3 & 2,40 & 1,47 & 1,06 & 1,89 & 1,66 \\
4 & 1,86 & 1,50 & 1,86 & 1,47 & 2,46 \\
\hline Jumlah & 8,16 & 6,90 & 5,83 & 5,82 & 7,73 \\
\hline Rata-rata & 2,04 & 1,72 & 1,46 & 1,45 & 1,93 \\
\hline
\end{tabular}


Amonia penting bagi beberapa jenis bakteri rumen dan merangsang pertumbuhan bakteri lainnya (Hungate, 1966). Kekurangan pasokan amonia akan mengakibatkan penurunan proses fermentasi dalam rumen, sehingga fungsi rumen terganggu. Amonia yang dibebaskan dalam rumen sebagian dimanfaatkan oleh bakteri untuk mensintesis protein mikroba (Abdoun et al. 2007). Sintesa protein mikroba di dalam rumen dinyatakan efisien jika dapat menyokong pertumbuhan mikroba secara maksimum dan produksi protein mikroba yang maksimum juga.

Kandungan serat kasar pada ampas bir cukup tinggi, sehingga akan sukar dan memerlukan waktu yang lama untuk dicerna oleh bakteri. Hal ini sesuai dengan pendapat Arora (1989) yang menyatakan bahwa makanan dengan kandungan serat kasar yang rendah mudah dicerna dan memerlukan waktu yang pendek per satuan berat. Ampas bir adalah sisa fermentasi yang sebagian besar terdiri atas pati dan gula dari gandum pada saat pembuatan bir (Cullison, 1978), sehingga merupakan sumber karbohidrat yang baik. Karbohidrat akan difermentasi dengan kecepatan yang cukup tinggi oleh mikroba rumen yang akan menghasilkan ATP (Adenosine Tri Phosphat) dan asam lemak terbang (VFA) yang terdiri atas asetat, propionat, dan butirat. Produk akhir utama dari makanan yang kaya akan karbohidrat struktural (tinggi akan serat kasar) adalah asetat, sedangkan produk akhir utama dari makanan yang kaya akan karbohidrat non struktural adalah propionat (Arora, 1989).

Hungate (1966) menyatakan bahwa hasil fermentasi karbohidrat dalam rumen adalah $\mathrm{CO}_{2}$, $\mathrm{CH}_{4}$, asam format, asam asetat, asam propionat, asam butirat, asam laktat, asam succinat, dan ethanol. Asam lemak terbang ini akan dimanfaatkan oleh induk semang sebagai sumber energi. Asam lemak terbang akan diserap oleh dinding sel rumen dan omasum, selanjutnya masuk ke dalam sistem biokimia sel dimana pembentukan energi terjadi. Jumlah energi yang terbentuk pada ternak ruminansia bergantung pada jumlah sumber energi yang dapat dibentuk oleh mikroba rumen.

\section{Pengaruh Perlakuan terhadap Jumlah Protozoa Rumen}

Protozoa merupakan salah satu jenis mikroba yang juga terdapat dalam rumen. Protozoa terdapat dalam jumlah yang lebih sedikit, namun ukurannya lebih besar dibanding bakteria. Jumlah protozoa dalam rumen lebih sedikit bila dibandingkan dengan jumlah bakteri, Tabel 3 merupakan jumlah protozoa dalam cairan rumen (in vitro) hasil penelitian.

Data Tabel 3 menunjukkan nilai rataan jumlah protozoa tertinggi diperoleh pada penggunaan $14 \%$ ampas bir (R2), yaitu sebanyak $12,6 \times 10^{7} \mathrm{sel} / \mathrm{mL}$, kemudian diikuti oleh pengunaan $21 \%$ ampas bir (R3) sebanyak $11,90 \times 10^{7} \mathrm{sel} / \mathrm{mL}, 28 \%$ ampas bir (R4) sebanyak $8,05 \times 10 \mathrm{sel} / \mathrm{mL}, 7 \%$ ampas bir (R1) sebanyak $7,85 \times 10^{7} \mathrm{sel} / \mathrm{mL}$ dan nilai terendah diperoleh pada penggunaan $0 \%$ ampas bir (R0), yaitu sebanyak 7,75 x $10^{7} \mathrm{sel} / \mathrm{mL}$.

Berdasarkan data yang diperoleh didapatkan hasil bahwa populasi protozoa cukup tinggi, yaitu dengan konsentrasi $10^{7} \mathrm{sel} / \mathrm{mL}$. Menurut Yokohama dan Johnson ${ }_{6}(1988)$, populasi protozoa berkisar antara $10-10 \mathrm{sel} / \mathrm{mL}$ cairan rumen. Hal ini bisa terjadi kemungkinan karena pakan yang diberikan cukup banyak mengandung konsentrat, dimana bahan-bahan penyusunnya besar

Tabel 3. Data Populasi protozoa rumen pada berbagai perlakuan ransum yang mengandung ampas bir

\begin{tabular}{crrrrr}
\hline \multirow{2}{*}{ Kelompok } & \multicolumn{5}{c}{ Perlakuan } \\
\cline { 2 - 6 } & \multicolumn{7}{c}{ R0 } & \multicolumn{7}{c}{ R2 } & R3 & R4 \\
\cline { 2 - 6 } & \multicolumn{7}{c}{----- x } & 10 & sel/ml cairan & rumen------------- \\
\hline 1 & 12,60 & 4,60 & 12,00 & 10,40 & 8,40 \\
2 & 5,60 & 7,40 & 16,20 & 9,40 & 12,20 \\
3 & 5,40 & 11,40 & 14,20 & 15,40 & 6,40 \\
4 & 7,40 & 8,00 & 8,00 & 12,40 & 5,20 \\
\hline Jumlah & 31,00 & 31,40 & 50,40 & 47,60 & 32,20 \\
\hline Rata-rata & 7,75 & 7,85 & 12,60 & 11,90 & 8,05 \\
\hline
\end{tabular}


berasal dari bahan pakan asal biji-bijian yang kandungan utamanya adalah karbohidrat. Selain itu, ransum penelitian mengandung ampas bir yang sebagian besar terdiri atas pati dan gula terlarut dari gandum. Pati merupakan karbohidrat non struktural yang dapat difermentasikan dengan kecepatan yang cukup tinggi oleh mokroba rumen (Arora, 1989). Selain memangsa bakteri, protozoa juga dapat memanfaatkan karbohidrat sebagai sumber makanannya. Menurut Arora (1989), protozoa akan lebih cepat tumbuh jika pakan pakan mengandung karbohidrat terlarut yang tinggi. Czerkawski (1986) menambahkan bahwa seluruh interaksi di dalam rumen akan mempengaruhi keseimbangan populasi mikroba rumen memanfaatkan karbohidrat sebagai sumber makanannya. Menurut Arora (1989), protozoa akan lebih cepat tumbuh jika pakan pakan mengandung karbohidrat terlarut yang tinggi. Czerkawski (1986) menambahkan bahwa seluruh interaksi di dalam rumen akan mempengaruhi keseimbangan populasi mikroba rumen.

Analisis Duncan menunjukkan bahwa penggunaan ampas bir tidak memberikan perbedaan yang nyata terhadap perubahan jumlah protozoa dalam cairan rumen domba. Hal ini menunjukkan bahwa penggunaan ampas bir pada berbagai tingkat penggunaan ampas bir tidak mempengaruhi populasi protozoa. Kemungkinan hal ini terjadi karena kualitas ransum setiap perlakuan pada penelitian ini relatif sama. Hal ini sama seperti pengaruh perlakuan terhadap bakteri, dimana hal tersebut dikarenakan kandungan zat makanan pada setiap ransum penelitian tidak berbeda jauh, sehingga jumlah protozoa yang dihasilkan pada setiap perlakuan tidak jauh berbeda.

Selain itu, jumlah bakteri yang dihasilkan setiap perlakuan yang tidak berbeda jauh (Tabel 2), menyebabkan jumlah protozoa juga tidak berbeda jauh. Hal ini dikarenakan selain mencerna partikel pakan, protozoa juga memakan bakteri. Sesuai dengan pendapat Czerkawski (1986) yang menyatakan bahwa protozoa memakan partikel makanan yang masuk ke dalam rumen, bakteri, bahkan protozoa yang berukuran kecil. Adanya interaksi di dalam rumen juga akan mempengaruhi keseimbangan populasi mikroba rumen (Czerkawski, 1986).

Protozoa merupakan salah satu dari populasi mikroba dalam rumen. Populasi mikroba dapat ditemukan pada lambung bagian depan, yaitu rumen, retikulum dan omasum, dari ternak ruminansia (Bohatier dalam
Jouany, 1991). Hungate (1966) menyatakan bahwa kehadiran protozoa tidak esensial untuk ruminansia. Hal ini karena biomassa protozoa yang besar mengurangi bakteri yang meninggalkan rumen. Menurut Yokohama dan Johnson (1988), keberadaan protozoa dalam rumen memegang peranan penting dalam mendegradasi hijauan pakan, namun pendapat lain mengatakan bahwa kehadiran protozoa diperlukan untuk mempertahankan $\mathrm{pH}$ rumen. Protozoa mempunyai kemampuan yang sangat kecil untuk mensintesa asam amino dan vitamin B kompleks (Arora, 1989). Protozoa memperoleh kedua zat makanan tersebut dari bakteri. Protozoa memakan partikel makanan yang masuk ke dalam rumen, bakteri, bahkan protozoa yang berukuran kecil, menguasai rumen dan kebanyakan dari protozoa tersebut tidak pernah meninggalkan rumen, sehingga diusulkan bahwa peranan protozoa mungkin bertindak sebagai buffer metabolik dalam rumen (Czerkawski, 1986). Pemberian pakan berserat kasar rendah secara kontinyu dengan melakukan perubahan secara pelan-pelan, dapat mengadaptasikan ruminansia terhadap karbohidrat yang mudah difermentasi.

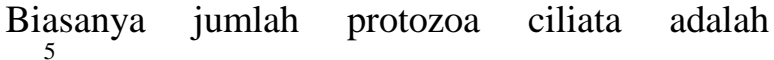
$10 \mathrm{sel} / \mathrm{mL}$ pada makanan berserat kasar tinggi, $\underset{6}{d a n}$ jumlah ini akan meningkat menjadi $10 \mathrm{sel} / \mathrm{mL}$ pada adaptasi gula-gula terlarut (Arora, 1989).

Jumlah protozoa yang tidak berbeda nyata menunjukkan bahwa penggunaan ampas bir tidak mempengaruhi ekologi rumen domba. Menurut Hungate (1966), faktor-faktor yang dapat meningkatkan jumlah protozoa yaitu, pemberian pakan biji-bijian dan pakan yang kaya akan protein, masa kebuntingan dan laktasi pada ternak, serta pemberian pakan yang telah digiling dan berbentuk pellet. Faktor-faktor yang mempengaruhi penurunan populasi protozoa rumen menurut Arora (1989), yakni keadaan kekurangan makanan dalam jangka lama, rendahnya $\mathrm{pH}$ dalam rumen, pemberian antibiotik seperti $\mathrm{CuSO}_{4}$ dan Acetarsol, serta pemberian makan lebih dari satu kali.

\section{Pengaruh Perlakuan terhadap Kandungan Volatile Fatty Acid (VFA)}

Tingginya kecernaan bahan organik yang terdapat pada ransum terutama karbohidrat dalam bentuk polisakarida dicerminkan oleh mudahnya bahan tersebut terdegradasi oleh mikroba rumen adalah VFA yang berupa asetat, butirat dan propionat. Produksi ini akan terkait dengan 
kemampuan bakteri, sedangkan aktivitas bakteri sangat ditentukan oleh nutrien yang tersedia
(Fahey dan Berger 1988). Rataan konsentrasi VFA hasil penelitian disajikan pada Tabel 4.

Tabel 4. Data kandungan VFA cairan rumen

\begin{tabular}{cccccc}
\hline \multirow{2}{*}{ Kelompok } & \multicolumn{5}{c}{ Perlakuan } \\
\cline { 2 - 6 } & R0 & R1 & R2 & R3 & R4 \\
\cline { 2 - 5 } & ----------------------------------mL-------------------------------- \\
\hline 1 & 146,65 & 142,00 & 121,10 & 107,65 & 70,00 \\
2 & 150,00 & 137,10 & 129,05 & 108,65 & 93,20 \\
3 & 148,50 & 127,40 & 125,10 & 118,75 & 89,25 \\
4 & 169,50 & 125,90 & 127,70 & 117,20 & 85,40 \\
\hline Jumlah & 614,65 & 532,40 & 502,95 & 452,25 & 337,85 \\
\hline Rataan & $153,66^{\mathrm{e}}$ & $133,10^{\mathrm{d}}$ & $125,74^{\mathrm{c}}$ & $113,06^{\mathrm{b}}$ & $84,46^{\mathrm{a}}$ \\
\hline
\end{tabular}

Keterangan : Superskrip berbeda pada baris yang sama menunjukkan berbeda nyata $(\mathrm{P}<0,05)$.

Tabel 4. memperlihatkan adanya perbedaan konsentrasi VFA antar perlakuan. Konsentrasi VFA total bervariasi 84,46-153,66 $\mathrm{mM}$, dengan konsentrasi VFA tertinggi, yaitu 153,66 mM diperoleh pada perlakuan R0, yaitu pada ransum tanpa penggunaan ampas bir, sedangkan konsentrasi VFA terendah, yaitu 84,46 $\mathrm{mM}$ diperoleh pada perlakuan $\mathrm{R} 4$, yaitu pada penggunaan ampas bir 40\%. Secara umum konsentrasi VFA cairan rumen berada dalam kisaran normal bagi ternak, seperti yang dikemukakan Sutardi (1977), bahwa kadar VFAyang terbaik untuk pertumbuhan optimum mikroba rumen, yaitu 80-160 mM. Asam lemak tersebut dibutuhkan sebagai kerangka karbon dan sumber energi dalam pembentukan sel mikrobia (Bergen, 1977; Rahayu et al. 2018).

Berdasarkan uji Duncan (Tabel 4) menunjukkan bahwa terdapat perbedaan yang nyata antara ransum tanpa penggunaan ampas bir dengan ransum yang menggunakan ampas bir. Hasil tersebut menunjukkan bahwa ransum yang diberi ampas bir menyebabkan penurunan konsentrasi VFA pada cairan rumen. Hal ini diduga karena sebagian ampas bir mengandung kulit biji (hull), dimana kulit tersebut masih banyak mengandung lignin, sehingga mikroba menjadi sulit dalam mendegradasi karbohidrat. Lignin yang tinggi akan berikatan kuat dengan selulosa dan hemiselulosa yang dapat menghambat fermentasi mikroba rumen (Hifizah, 2013). Sesuai dengan pendapat Linko (1976) keberadaan lignin yang cukup tinggi dapat menahan kerja enzim selulase yang dihasilkan mikroba. Diperkuat dengan pendapat Preston dan Leng (1987), bahwa keterikatan serat kasar dalam bentuk senyawa kompleks akan menghambat kecernaan ransum.

Selain ampas bir juga diduga mempunyai zat anti nutrisi, yaitu tannin, karena dalam pembuatan ampas bir menggunakan bahan yang disebut hop. Menurut Palmer (2006) hop merupakan sejenis tanaman perdu yang banyak mengandung tannin. Tannin mempunyai sifat berikatan dengan karbohidrat struktural seperti selulosa, hemiselulosa, dan pectin. Hal ini sesuai dengan pendapat Tangendjadja et al. (1992) yang menyatakan bahwa tannin memiliki sifat utama dapat berikatan dengan protein atau polimer lainnya seperti selulosa, hemiselulosa, dan pectin guna membentuk suatu ikatan kompleks yang stabil. Ikatan yang kompleks tersebut menyebabkan mikroba memiliki keterbatasan dalam merombak karbohidrat, sehingga banyak karbohidrat yang tidak dicerna oleh mikroba yang medegradasi dinding sel. Akibat dari sedikitnya karbohidrat yang terdegradasi maka konsentrasi VFA menjadi menurun.

\section{Pengaruh Perlakuan terhadap Kandungan Amonia (N-NH $)_{3}$ Cairan Rumen}

Produksi $\mathrm{NH}_{3}$ cairan rumen diperoleh dari pencernaan protein ransum/bahan pakan di dalam rumen. Proses perombakan bahan pakan menjadi $\mathrm{N}-\mathrm{NH}_{3}$ dilakukan oleh mikroba (Jenny et al. 2012). Aktivitas mikroba di dalam rumen sangat berperan penting. Bahan pakan lebih dahulu dimanfaatkan oleh mikroba sebagai sumber protein untuk pertumbuhan sel mikroba, kemudian mikroba rumen dimanfaatkan oleh ternak sebagai sumber protein mikroba yang memiliki nilai nutriein yang tinggi (Suryani et al. 2014). Rataan konsentrasi $\mathrm{N}-\mathrm{NH}_{3}$ pada masingmasing perlakuan disajikan pada Tabel 5 .

Tabel 5 memberikan informasi bahwa penggunaan ampas bir dalam ransum memberikan dampak terhadap jumlah protein 
yang dapat dirombak oleh mikroba rumen yang tercermin dari nilai konsentrasi $\mathrm{N}^{-\mathrm{NH}_{3}}$ cairan rumen. Konsentrasi $\mathrm{N}_{-} \mathrm{NH}_{3}$ cairan rumen perlakuan bervariasi antara 5,55-9,30 mM, dengan konsentrasi tertinggi, yaitu 9,30 $\mathrm{mM}$ diperoleh pada perlakuan R1, yaitu pada penggunaan ampas bir pada tingkat 10\%, sedangkan konsentrasi terendah 5,55 $\mathrm{mM}$ diperoleh pada perlakuan R4, yaitu pada penggunaan ampas bir tingkat 40\%. Secara umum rataan konsentrasi $\mathrm{N}-\mathrm{NH}_{3}$ masih dalam kisaran normal bagi ternak. Kisaran rataan konsentrasi berkisar anatar 5,55-9,30 mM. Menurut Sutardi (1979) kisaran optimum untuk $\mathrm{N}-\mathrm{NH}_{3}$ berkisar antara 4-12 mM.

Tabel 5. Data kandungan $\mathrm{N}-\mathrm{NH}_{3}$ cairan rumen

\begin{tabular}{|c|c|c|c|c|c|}
\hline \multirow{3}{*}{ Kelompok } & \multicolumn{5}{|c|}{ Perlakuan } \\
\hline & R0 & $\mathrm{R} 1$ & $\mathrm{R} 2$ & R3 & $\mathrm{R} 4$ \\
\hline & \multicolumn{5}{|c|}{---------------mL-------------- } \\
\hline 1 & 8,55 & 9,4 & 7,25 & 4,7 & 6,05 \\
\hline 2 & 8,95 & 9,2 & 7,5 & 7,47 & 4 \\
\hline 3 & 9,1 & 9,7 & 8,7 & 5,6 & 3,95 \\
\hline 4 & 9,65 & 8,9 & 7,85 & 5,65 & 8,2 \\
\hline Jumlah & 36,25 & 37,2 & 31,3 & 23,42 & 22,2 \\
\hline Rataan & $9,06^{b}$ & $9,30^{\mathrm{b}}$ & $7,83^{b}$ & $5,86^{\mathrm{a}}$ & $5,55^{\mathrm{a}}$ \\
\hline
\end{tabular}

Keterangan : Superskrip berbeda pada baris yang sama menunjukkan berbeda nyata $(\mathrm{P}<0,05)$.

Bervariasinya nilai konsentrasi $\mathrm{N}-\mathrm{NH}_{3}$ yang dihasilkan sangat erat kaitannya kualitas dan tingkat kelarutan protein ransum. Hal ini sejalan dengan pendapat Erwanto (1995) bahwa konsentrasi $\mathrm{N}-\mathrm{NH}_{3}$ dalam cairan rumen erat kaitannya dengan kualitas dan tingkat kelarutan protein ransum dalam cairan rumen, semakin mudah larut suatu protein makan akan semakin cepat didegradasi menjadi $\mathrm{N}-\mathrm{NH}_{3}$.

Berdasarkan uji Duncan (Tabel 5) menunjukan bahwa terjadi penurunan kandungan $\mathrm{N}-\mathrm{NH}_{3}$ yang nyata $(\mathrm{P}<0,05)$ dengan semakin tingginya penggunaan ampas bir dalam ransum terutama pada perlakuan R3 dan R4. Penurunan ini disebabkan penggunaan hop dalam pembuatan ampas bir, dimanan hop banyak mengandung tanin. Tanin dapat mengikat protein, sehingga sulit didegradasi oleh bakteri proteolitik menjadi $\mathrm{N}-\mathrm{NH}_{3}$. Sesuai dengan dengan pendapat Mangan (1988) dan Makkar dan Becker (1998) yang menyatakan bahwa tanin membentuk ikatan dengan protein, sehingga protein tidak terdegradasi dalam rumen. Hal ini didukung juga dengan pernyataan dari Tangendjadja (1992) dan Hernaman et al. (2005) bahwa tanin dapat membentuk ikatan dengan protein guna membentuk suatu ikatan kompleks yang stabil.

\section{KESIMPULAN}

Berdasarkan data-data tersedia, penggunaan ampas bir tidak mempengaruhi populasi bakteri dan protozoa rumen, namun mempengaruhi fermentabilitas dengan terjadinya penurunan konsentrasi VFA dan $\mathrm{N}-\mathrm{NH}_{3}$ cairan rumen.

\section{UCAPAN TERIMAKASIH}

Terimakasih disampaikan kepada Laboratorium Nutrisi Ternak Ruminansia dan Kimia Makanan Ternak, Fakultas Peternakan Universitas Padjadjaran atas fasilitas penggunaan alat laboratorium, sehingga penelitian dapat berlangsung dengan baik.

\section{DAFTAR PUSTAKA}

Abdoun, K., F. Stumpff and H. Martens. 2007. Ammonia and urea transport across the rumen epithelium: A Review Animal Health Research Reviews 7(1/2); 43-59

Arora, S.P. 1989. Pencernaan Mikroba Pada Ruminansia. Diterjemahkan oleh Retno Muwarni. Gadjah Mada University Press. Yogyakarta. $44-49$.

Bergen, W. G. 1977. Factors affecting growth yields of micro-organisms in the rumen. Trop. Anim. Prod. 4: 13-20.

Bohatier, J. 1991. The Rumen Protozoa: Taxonomy, Cytology and Feeding 
Behaviour. In : Jouany, J.P. Rumen Microbial Metabolism and Ruminant Digestion. Institut National de la Recherche Agronomique. Paris. 27 - 38.

Briggs, D.E. 1978. Barley. $1^{\text {st }}$ ed. Chapman and Hall Halsted Press Book. Jhon Willey And Son's, Inc. New York.

Cullison, A.E. 1978. Feed and Feeding. PrenticeHall of India Private Limited. New Delhi. 181.

Czerkawski, J.W. 1986. An Introduction to Rumen Studies. Pergamon Press. Oxford, New York, Toronto, Sydney, Frankfurt. $109,118-120$.

Erwanto. 1995. Optimalisasi Sistem Fermentasi Rumen melalui Suplementasi Rumen Sulfur, Defaunasi, Reduksi Emisi Metan dan Stimulasi Pertumbuhan Mikroba pada Ternak Ruminansia. Disertasi. Program Doktor, PPS. IPB. Bogor.

Gaspersz, V. 1995. Tehnik Analisis dalam Penelitian Percobaan. Transito. Bandung

Hernaman, I., U.H. Tanuwiria and M.F. Wiyatna. 2005. Pengaruh penggunaan berbagai tingkat kulit kopi dalam ransum penggemukan sapi potong terhadap fermentabilitas rumen dan kecernaan invitro. Bionatura 7 (1) : 46-50

Hernaman, I., A. Budiman, S. Nurachma, dan K. Hidajat. 2015. Kajian in vitro subtitusi konsentrat dengan penggunaan limbah perkebunan singkong yang disuplementasi kobalt $(\mathrm{Co})$ dan seng $(\mathrm{Zn})$ dalam ransum domba. Buletin Peternakan 39 (2) : 71-77.

Hifizah, A. 2013. Perbandingan efektifitas inokulum cairan rumen kerbau dan sapi pada jerami. Jurnal Teknosains 7(2) : 175-188

Hungate, R.E. 1966. The Rumen and Its Microbes. Academic Press. New York and London. 8 - 12; 127.

Jenny, I., Surono dan M. Christiyanto. 2012. Produksi amonia, undegraded protein dan protein total secara in vitro bungkil biji kapuk yang diproteksi dengan tanin alami. Animal Agricultural Journal, 1 (1) : $77-284$

King, H.B. 1974. Brewers Grains. A Natural for Good Properties and Uses. United States Brewer's Association, Inc. Washington DC. 1-4.

Kreier, J.P. and J.R. Baker. 1993. Parasitic Protozoa. Academic Press, Inc. $2^{\text {nd }}$ ed. 3 ; 4.

Linko, M.L. 1976. Biological Treatment of Straw on Commercial Farm Levels. Proc. of New Feed Resources. FAO. Rome.

Makkar H.P.S. and K. Becker. 1998. Adaptation of cattle to tannins: role of protein-rich proteins in oak-fed cattle. Anim Sci 67 (2) $277-281$.

Mangan J.L., 1988. Nutritional effects of tannins in animal feeds. Nutr Res Rev 1, 209231.

Morrison, F.B.1961. Feed and Feeding Abrieged. $9^{\text {th }}$ ed. The Morrison Publ. Co. Clinton. Iowa. 297; 584.

Ogimoto, K. and S. Imai. 1981. Atlas of Rumen Microbioloby. Japan Societies Press.

Stewart, C.S. 1991. The Rumen Bacteria. In : Jouany, J.P. Rumen Microbial Metabolism and Ruminant Digestion. Institut National de la Recherche Agronomique. Paris. 15 - 26.

Suryani, N.M., I.K.M. Budiasa dan I.P.A. Astawa. 2014. Fermentasi rumen dan sintesis protein mikroba kambing Peranakan Ettawa yang diberi pakan dengan komposisi hijauan beragam dan level konsentrat berbeda. Majalah Ilmiah Peternakan 17 (2): 56-60

Palmer, J.J. 2006. How to Brew: Everything you need to know to brew beer right the first time. Brewer Publications. USA.

Preston, T.R. and R.A. Leng. 1987. Matching Ruminant Production System with Available Resourch in The Tropics and 
Sub-Tropics. Penambul Books Armidale, New South Wales. 21-128.

Purbowati, E., E. Rianto, W.S. Dilaga, C.M.S. Lestari, dan R. Adiwinarti. 2014. Karakteristik cairan rumen, jenis, dan jumlah mikrobia dalam rumen sapi Jawa dan Peranakan Ongole. Buletin Peternakan 38(1): 21-26.

Rahayu, R.I., A. Subrata, dan J. Achmadi. 2018. Fermentabilitas ruminal in vitro pada pakan berbasis jerami padi amoniasi dengan suplementasi tepung bonggol pisang dan molasses. Jurnal Peternakan Indonesia 20 (3): 166-174.

Sutardi, T. 1980. Landasan Ilmu Nutrisi. Jilid 1. Departemen Ilmu Makanan Ternak. Fapet IPB. Bogor. 6 - 10 .
Tangendjaja, B., Wina, E., Ibrahim, T. and Falmer, B. 1992. Kaliandra (Calliandra calothyrsus) dan Pemamfaatannya. Balai Penelitian Ternak dan The Australian Centre For International Agriculture Research ( ACIAR).

Tilley, J.M.A. and Terry. R.A. 1963. A two stage technique for the in vitro digestion of the forage crops. J. Brit. Grassl. Soc. (18) 2 : $104-106$.

Yokohama, M.T. and K.A. Johnson.1988. Microbiology of The Rumen and Intestine. Church, D.C. ed. Digestive Physiology and Nutrition of Ruminant. Prentice Hall, New Jersey 07632. 125- 